\title{
The consumption of live music in different languages: a quantitative approach
}

\author{
Michael Spanu \\ University of Lorraine, Nancy, France \\ Nicolas Sommet \\ University of Lausanne, Lausanne, Switzerland, and \\ Jean-Marie Seca \\ University of Lorraine, Nancy, France
}

\begin{abstract}
Purpose - The consumption of music performed in different languages represents a significant aspect of the contemporary cultural experience. This phenomenon questions how different languages mediate music consumption in specific national contexts. In this paper, the authors investigate the case of live music consumption in France.

Design/methodology/approach - The authors surveyed 428 persons who saw 159 artists either performing in French or in English in 46 locations around Paris, France. The authors tested the effect of the language of the concert on three dimensions of music consumption: singing in unison, appraisal of the lyrics and dancing.

Findings - Multilevel analysis revealed that English was positively associated with dancing, whereas French was positively associated with the appraisal of the lyrics. The authors found no evidence that the language of the concert was associated with differences in singing in unison.

Originality/value - Results are discussed with respect to language diversity in the context of globalised popular music consumption.
\end{abstract}

Keywords Language, Music, Cultural diversity, Cultural consumption

Paper type Research paper

\section{Introduction}

Music in different languages is at the heart of cultural production and consumption in our globalised world (Cicchelli et al., 2018). It also contributes to multiple forms of cultural interactions (Ninoshvili, 2009) and identifications through social and emotional experiences (Taylor, 2014; Blommaert, 2010; Pennycook, 2006). This paper aims at examining differences in the consumption of music sung in different languages, in a context where the official national language coexists with a global and hegemonic language. The case of France embodies is quite well in such a context, given its historical relation to monolingual ideologies (Cerquiglini, 2006; Balibar, 1985) and its actual connections with global culture (Dauncey, 2017; Forsdick, 2017).

Indeed, French cultural consumption is nowadays characterised by an important linguistic mingling, especially between English and French. Younger generations consume a great deal of media contents in their original language. In 2008, more than half of the 15-29 years old watching TV mainly in a foreign language reported watching it in English (Octobre, 2014). They also listened to more international mainstream music in English than their elders: $41 \%$ of the 15-29 years old declared that they prefer listening to music in English (vs $11 \%$ for older generations; Octobre, 2014). In terms of diffusion, between 2006 and 2015, the share of French-language music broadcast on national radio experienced a $7 \%$ decrease (Véronique and Martiréné, 2015). In 2015, French politicians strongly criticised French commercial radios for the lack of language diversity of their programme, targeting the practice of plugging a small number of artists singing in French (Franque, 2015). Ten songs could sometimes

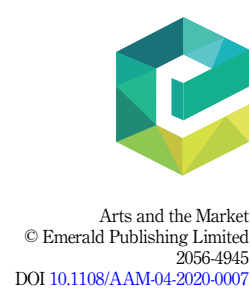


represent $75 \%$ of the total number of French songs (Morio, 2015). It is worth noting that, since 1966, French radios are required to play at least $40 \%$ of songs in French (CSA, 1996). An amendment was made in 2015 to force radios to propose a more diverse range of music in French. However, digital native media such as music streaming platforms are not subject to any regulation with respect to language, thus creating tensions within the media industry (Reynaud, 2016).

Thelinguistic mingling of French music consumption is also ideological, as theinternational spread of English has often been theorised as cultural imperialism (Mattelart, 2015; Schiller, 1984), which can be defined as a mechanism through which hegemonic cultural and linguistic codes are imposed on dominated populations. In France, the use of English in the arts is often seen as carrying "American" values (e.g. individualismand consumerism), which is supposedly in opposition to an idealised set of "French" artistic values (e.g. non-commercial, serious and protest like, see Regourd, 2004; Wall, 1987). Historically, the so-called "Americanisation" of French society has been one of the main arguments for promoting protectionist policies within the cultural field (Poirrier, 2006), targeting music production and distribution. If the recent growth in the use of English within popular music radio airplay has rekindled the debate on cultural homogenisation, other studies on European countries' charts show that the number of national language songs is generally increasing again after a substantial decline in the 1980s and 1990s (Achterberg et al., 2011; Wolther, 2008). Additionally, the global digital context is increasingly viewed as favouring a new kind of mainstream pop music in other languages than English, such as Spanish and Korean (Sullivan, 2019). These multiple and apparently contradictory phenomena question how different languages coexist and how they are received by listeners in a same globalised cultural environment.

Our definition of language is based on the notion of social practice. In other words, languages are practices related to other dimensions of social activity and not objects or essences in a social vacuum (Pennycook, 2010). Languages are always local or "relocated" regardless of their national or foreign designation. Depending on the context, languages involve certain emotions, styles and identifications. For instance, English can be considered a "global" language because it responds to the unprecedented need of international communication (Crystal, 2012), but it is more than a "functional" tool of communication. Regarding music production, the sole fact that artists around the world use and adapt English proves the complexity of its meaning. Outside the English-speaking countries, popular music sung in English is not only related to a legacy of pop and rock (Larkey, 2000) or a way of going "global" (De Meyer, 1996), it can express transnational and counter-hegemonic identities, as in the cases of Brazilian manguebeat (De Figueiredo, 2015), Asian hip hop, (Alim and Pennycook, 2007) and Indonesian punk (Wallach, 2003). Yet English can also correspond to cultural homogenisation/standardisation as in the case of K-pop (Jin and Ryoo, 2014). As regards to national languages, such as French in France or German in Germany, they do not necessarily embody a fixed national identity or "ethnonational uniqueness" (Regev, 2011). They can express alternative versions of national belonging (Kahnke, 2013; Krause, 2008; Guibert, 2003; Larkey, 1992) or other social identities, such as class, gender or race. In postcolonial contexts, the use of a particular vernacular can index national identity and independence, such as in dancehall music in Jamaica (Farquharson, 2017; Devonish and Jones, 2017).

More generally, in popular music, singers not only use specific languages or language varieties to target specific audiences but also to perform what they consider to be authentic cultural identities in a globalised world (Duncan, 2017; Aleshinskaya and Gritsenko, 2017; Spanu, 2019a; Benson, 2013; Dorin, 2005; Mitchell, 2001). Here, authenticity is not to be understood as a fixed attribute but rather as a performance tied to specific social representations of what is original/unheard or legitimate/ritualised (Buch, 2014; Seca, 2009). This idea suggests that language reception in a musical context plays a certain role in defining authenticity and cultural identities (Van der Hoeven et al., 2016). 
In this paper, we aim at examining differences in the consumption - by French audiences of music sung in two different languages: English and French. We chose to focus on one type of music consumption: live performances. Although music is nowadays widely distributed online and consumed individually (Sinclair and Green, 2016; Nowak and Bennett, 2014), concerts remain as a crucial part of the music experience (Cluley, 2009) and economy in modern societies (Ballico and Carter, 2018; Guibert and Sagot-Duvauroux, 2013; Holt, 2010). Empirical research in Belgium showed that artist-related variables, such as language, nationality and popularity, are the major determinants in the growth in ticket prices (Decrop and Derbaix, 2014). These results show the consumer's willingness to pay a higher price for artists performing in its own language than for artists performing in English, but they do not address the affective dimension of music consumption in regards to language.

Concerts are ideal and convenient environments to document and analyse people's verbal and non-verbal responses to music performances in relation to a language (Burland and Pitts, 2016). From the perspective of the audience, the principal manifestation of language is the lyrics sung by the artist. By definition, lyrics are the result of an interaction of language with musical features. In this sense, the reception of lyrics exceeds the usual pragmatic function of language and reaches what can be called a "poetic" function (Marc Martínez, 2011). This poetic function is predominantly related to the expression of emotions (Schubert, 2013). Previous empirical studies showed that textual and musical features can both be successfully used for emotion recognition in songs (Mihalcea and Strapparava, 2012), but also that lyrics appear to have more power to direct mood change compared to music alone, and can imbue a particular melody with affective qualities (Ali and Peynircioğlu, 2006; Stratton and Zalanowski, 1994).

The academic literature focused on language in popular music often relies on methodologies that aim to capture "literate" practices of listening (e.g. collective listening in a classroom and text interpretation). These methods are specific forms of "control of reception," as "the text visually presents itself as a structured unit and can be reconstructed as a coherent whole" (Moser, 2007, p. 292) and emphasise the textual value of a song [1]. However, lyrics can also be referred as "structures of sound" (Frith, 1989) in which languages matter less for the meaning they provide than for the way they mingle with the music. Nonverbal dimensions of language such as sound and rhythm play a crucial role in the reception of lyrics; the musicality of language "is integrated with music directly and therefore often figures as an instrument" (Moser, 2007, p. 295). Thus, as a first outcome variable of the consumption of language in music, we consider the extent to which the audience is emotionally affected by the lyrics during a concert, or, in other words, the extent to which individuals appreciate the lyrics.

This appreciation is necessarily related to a minimum level of understanding. Even if English is more and more taught and practiced among the French population, the level of proficiency remains rather moderate. Education First's database ranks France 22 out of 26 European countries, based on tests including reading and listening sections in English (Education First, 2019). In spite of high or low proficiency in English, the first language is typically felt to have superior emotional strength and resonance compared to languages that have been acquired later in life (Dewaele, 2015, 2010). In a musical context, it is likely that native French speakers are more receptive to the semantic aspects of the lyrics when a song is in French, as literal familiarity has a well-known effect on the social sharing of emotions (Cotton, 1981; Rimé, 2005; Schachter, 1964; Schachter and Singer, 1962). Thus, we formulated the following first hypothesis:

H1. Audience members will show a greater appreciation of the lyrics when the concert is performed in their native language (French) rather than in a foreign language (English). 
We then need to consider other forms of language reception that entail various "body techniques" (Crossley, 2015), such as singing in unison and dancing. Singing in unison (also referred as singing along) is a relatively widespread and spontaneous practice among popular music audiences. It is a cooperative group activity that enables people to express engagement (Bennett, 1997) to communicate together (Jackson, 2004) and to feel virtually connected to the performing artist (Packer and Ballantyne, 2011), thus creating a certain sense of community (Ballou, 2009; Morton, 2013). Because nationhood is one of the most iconic forms of community, it is strongly related to the national language and still relevant in contemporary globalised societies (Jones and Merriman, 2009; Billig, 1995). Besides, due to necessary active linguistic and social engagement, the practice of singing along may not easily occur when the audience is less familiar with the language of the concert. Thus, we formulated the following second hypothesis:

H2. Audience members will sing more in unison when the concert is performed their native language (French) rather than in a foreign language (English).

Dancing is also a common body technique during popular music events, but it has often been dismissed as pure entertainment and opposed to more "serious" listening practices. In fact, this assumption is an aspect of "the way in which high culture was established in Europe and the United States in the nineteenth century" (Frith, 1989, p. 124). Classical performances command stillness and mental concentration, whereas popular music events trigger physical responses. However, this physical aspect goes far beyond a mindless listening practice or a calculative consumer action (Hewer and Hamilton, 2010). It suggests that the musical experience cannot always be interpreted in rational terms and may allow other forms of understanding/identification, especially through sensuality. More generally, dancing stands for both "collective" and "musical" participation, whereas the mind is associated with "individuality," "the self" (Frith, 1989, pp. 142-143) and the "unconscious of crowd" (Moscovici, 1985). In this sense, we can consider dancing as another manner of experiencing the music in relation to language, especially in the case of a foreign language that is less understood and familiar than the native language. Indeed, if the level of understanding and familiarity of the language sung is low, listeners will focus their attention on other musical aspects, such as rhythm, to create meaning and develop their own idea of authenticity (Szego, 2003). Thus, formulated the following third hypothesis:

H3. Audience members will dance more when the concert is performed in a foreign language (English) rather than in their native language (French).

The complete material (i.e. full questionnaire), raw de-identified dataset (in .xlsx and .csv) and Stata do-file enabling one to reproduce our findings can be found at https:/figshare.com/s/ 7a5647251bae7a3ccece.

\section{Method \\ Participants and procedure}

The study was conducted in two phases. The first half of participants $(n=234)$ completed our questionnaire in 2015. Given the lack of clarity in some findings, the other half of participants $(n=194)$ again completed our questionnaire in 2018 . We adjusted the alpha level for multiple comparisons: as we collected the sample in two stages, the number of statistical tests was doubled, and the critical $p$-value was divided by two $\left(\alpha_{\text {adj }}=\alpha / 2=0.025\right)$ to maintain a type-I error rate of 5\% (Cramer et al., 2016).

Participants were recruited in two ways. They were either (1) directly reached after concerts within or around Paris and given a paper questionnaire or (2) contacted through the Facebook page of concerts and given a link to the online version of the same questionnaire [2]. 
A total of 428 participants took part in the study. Of participants, 18 were excluded $a$ priori because they did not speak French as a first language, six others because the artist or band they saw performed in another language than English or French (i.e. our focal independent variable) and three others due to missing data. The final sample comprised $N=401$ participants who saw $K=159$ performing artists, located in 46 different venues (see Table A1 for the names of the artists and venues and most of which were located in Paris).

There were 166 men and 235 women, with a mean age of $M_{\text {age }}=33.13(\mathrm{SD}=11.48)$, and $44.64 \%$ of whom had a mother with a post-secondary diploma [3]. About half of the participants reported seeing an artist or band performing in English $(n=218,54.36 \%)$, whereas the other half reported seeing an artist or band performing in French $(n=183$, $45.64 \%)$ [4].

\section{Dependant variables}

Appraisal of the lyrics. Using a scale ranging from 1 ("not at all") to 5 ("very much"), respondents reported the extent to which they had liked the lyrics during the show $(M=4.55$, $\mathrm{SD}=0.79)[5]$.

Singing in unison. Using a scale ranging from 1 ("never") to 5 ("on most of the songs"), respondents reported the frequency with which they had sung along during the show $(M=2.97, \mathrm{SD}=1.30)$.

Dancing. Using a scale ranging from 1 ("never") to 5 ("on most of the songs"), respondents reported the frequency with which they had danced, moved or physically responded to the music in any manner during the show $(M=4.25, \mathrm{SD}=1.22)$.

\section{Control variables}

English language skills. Using a scale ranging from 1 ("a few words") to 4 ("bilingual"), respondents reported the extent to which they mastered the English language $(M=2.78, \mathrm{SD}=0.85)$.

Attachment to the artist before the concert. Live music experience and engagement is known to be determined by preparation and anticipation (Burland and Pitts, 2016), for instance through the prior relation to the performing artist. Moreover, previous research on the Parisian indie scene indicated that the level of attachment to a band is modulated by a language, thereby influencing one's behaviours during concerts (Spanu and Seca, 2016). We therefore assessed and controlled for this variable: Using a scale ranging from 1 ("never") to 5 ("more than 50 times"), respondents reported the number of times they had listened to the concert artist's music in the past six months $(M=3.82, \mathrm{SD}=1.21)$.

Concert attendance. Live music experience and engagement is known to be also determined by concert-goers habits (Burland and Pitts, 2016) and, in particular, by one's frequency of attendance to concerts. Previous ethnographic research indicated that frequent concertgoers tend to observe more and pay specific attention to lyrics during the concert (Spanu and Seca, 2016). We therefore assessed and controlled for this variable: using a scale ranging from 1 ("none") to 5 ("at least once a week"), respondents reported the number of concerts they had attended in the past months $(M=3.28, \mathrm{SD}=0.89)$.

Accompanying. Previous ethnographic research indicated that individual concertgoers tend to observe more and pay a specific attention to lyrics during the concert compared to groups (Spanu and Seca, 2016). We therefore assessed and controlled for this variable: respondents reported if they came to the concert alone (18.70\%) or accompanied $(81.30 \%)$.

Patriotic attitudes. Extant research indicated that patriotic attitudes are positively associated to domestic cultural consumption (Bekhuis et al., 2013; Meuleman et al., 2013; Meuleman and Lubbers, 2014). We therefore assessed and controlled for this variable: using a scale ranging from 1 ("not proud at all [of my nationality]") to 5 ("very proud"), respondent reported the extent to which they had patriotic attitudes $(M=3.56, \mathrm{SD}=1.20)$. 


\section{Results}

Overview of the multilevel analysis

We used cross-classified multilevel linear regression modelling. We treated participants (level-1 units) as cross-classified by artists (level-2a units) and by venues (level-2b units). This approach enabled us to disentangle the between-participant variance from both the within-artist and the within-venue variance. The units are said to be cross-classified because participants seeing a given artist or band are not necessarily subclassified into the same venue (i.e. as similar artists may perform in different places and vice versa). Given the complexity of the data structure, we used MCMC (with 50,000 iterations) as the estimation method (Dunn et al., 2015). It uses the Bayesian framework and we report both Bayesian 95\% credibility intervals and traditional frequentist $p$-values. As previously stated, an adjusted alpha of 0.025 was used as the cut-off for significance.

Each outcome variable (i.e. appraisal of the lyrics, singing in unison and dancing) was linearly regressed on our focal level-2 independent variable, namely the language of the artist $(-0.5=$ English; $+0.5=$ French). We controlled for the following lower level covariates: sex $(-0.5=$ male; $+0.5=$ female $)$, age, mother's education, English languageskills, attachment to the artist before the concert, concertattendance, accompanying $(-0.5=$ alone; $+0.5=$ accompanied $)$ and patriotic attitudes. The same three models excluding the aforementioned covariates are presented in Table A2. Random effects were theoretically non-relevant and were not taken into account (see Sommet and Morselli, 2018).

For each outcome variable, we ran two series of preliminary analyses. First, we built an unconditional means model (including no predictors) in order to estimate the intraclass correlation coefficients (ICCs). Second, we ran a complete analysis of covariance aimed at determining the need for controlling the first-order interactions with our focal independent variable (i.e. language of the artist; see Yzerbyt et al., 2004).

\section{Appraisal of the lyrics}

Preliminary analyses. First, the unconditional means models revealed that at level $2 \mathrm{a}, \mathrm{ICC}_{2 \mathrm{a}}=0.03$, whereas at level $2 \mathrm{~b}$, it was $\mathrm{ICC}_{2 \mathrm{~b}}=0.06$. This indicated that $3 \%$ of the variance in the appraisal of the lyrics was explained by between-artist differences and $6 \%$ of the variance was explained by between-venue differences. Second, the analysis of covariance revealed an interaction between language and attachment to the artist. Thus, the interaction was kept in the final model.

Main analysis. Table 1 (first column from the right) presents the full set of predictors and results. Consistent with our first hypothesis, we observed a positive effect of language, $B=0.30,95 \%$ CI [0.15, 0.45], $p<0.001$ (see Figure 1, left panel). Specifically, participants seeing artists performing in French, $M=4.72,95 \% \mathrm{CI}[4.56,4.87]$ reported liking the lyrics better than participants seeing artists performing in English, $M=4.42,95 \% \mathrm{CI}[4.28,4.55]$.

As mentioned previously, we observed an interaction between language and attachment to the artist, $B=-0.20,95 \% \mathrm{CI}[-0.32,-0.09], p<0.001$. Specifically, the effect of language on appraisal of the lyrics was positive for participants with low levels of attachment to the artist (+1 SD), $B=0.55,95 \%$ CI $[0.35,0.76], p<0.001$ but not different from zero for participants with high levels of attachment to the artist (-1 SD), $B=0.05,95 \% \mathrm{CI}[-0.16$, $-0.26], p=0.319$ (see Figure 2).

Additionally, we observed effects of three of our covariates. First, appraisal of the lyrics was lower for men than for women, $B=-0.21,95 \%$ CI $[-0.35,-0.07], p=0.003$. Second, appraisal of the lyrics was positively associated with attachment to the artist, $B=0.28,95 \%$ CI $[0.22,0.34], p<0.001$.

\section{Singing in unison}

Preliminary analyses. First, the unconditional means models revealed that at level 2a, $\mathrm{ICC}_{2 \mathrm{a}}=0.28$, whereas at level $2 \mathrm{~b}$, it was $\mathrm{ICC}_{2 \mathrm{~b}}=0.14$. This indicated that $28 \%$ of the variance 
in singing in unison was explained by between-artist differences and $14 \%$ of the variance was explained by between-venue differences. Second, the analysis of covariance did not reveal significant interactions between language and our covariates. Thus, none of the interaction terms were kept in the final model.

Main analysis. Table 1 (second column from the right) presents the full set of predictors and results. Inconsistent with our second hypothesis, the effect of language was not significantly different from zero, $B=0.22,95 \%$ CI $[-0.08,0.51], p=0.140$ (see Figure 1 , middle panel).

However, we observed effects of two of our covariates. First, singing in unison was lower for men than for women, $B=-0.37,95 \% \mathrm{CI}[-0.59,0.17], p=0.001$. Second, singing in unison was positively associated with attachment to the artist, $B=-0.42,95 \% \mathrm{CI}[0.34,0.51], p<0.001$.

\section{Dancing}

Preliminary analyses. First, the unconditional means model revealed that at level 2a, $\mathrm{ICC}_{2 \mathrm{a}}=0.26$, whereas at level $2 \mathrm{~b}$, it was $\mathrm{ICC}_{2 \mathrm{~b}}=0.02$. This indicated that $26 \%$ of the variance in dancing was explained by between-artist differences and $2 \%$ of the variance was explained by between-venue differences. Second, the analysis of covariance revealed an interaction between language and concert attendance. Thus, this interaction term was kept in the final model.

Main analysis. Table 1 (third column from the right) presents the full set of predictors and results. Consistent with our third hypothesis, we observed a negative effect of language on dancing, $B=-0.47,95 \% \mathrm{CI}[-0.82,-0.14], p=0.006$ (see Figure 1, right panel). Specifically, participants seeing artists performing in French, $M=3.84,95 \%$ CI [3.55, 4.14], danced less than participants seeing artists performing in English, $M=4.32,95 \% \mathrm{CI}[4.08,4.56]$.

As mentioned previously, we observed an interaction between language and accompanying, $B=0.68,95 \%$ CI $[0.09,1.27], p=0.024$. Specifically, the effect of language on dancing was negative for participants attending concerts alone, $B=-0.82,95 \% \mathrm{CI}[-1.38$, $-0.26], p=0.004$, but not different from zero for participants attending concerts accompanied, $B=-0.14,95 \% \mathrm{CI}[-0.44,-0.16], p=0.376$ (see Figure 3).

\begin{tabular}{|c|c|c|c|c|c|c|}
\hline & \multicolumn{2}{|c|}{ Appraisal of the lyrics } & \multicolumn{2}{|c|}{ Unison singing } & \multicolumn{2}{|c|}{ Dancing } \\
\hline & $B$ & $95 \% \mathrm{CI}$ & $B$ & $95 \% \mathrm{CI}$ & $B$ & $95 \% \mathrm{CI}$ \\
\hline Intercept & $4.57^{* * * *}$ & {$[4.44,4.69]$} & $2.77^{* * * *}$ & {$[2.53,2.99]$} & $4.08^{* * * *}$ & {$[3.87,4.29]$} \\
\hline $\begin{array}{l}\text { Language of the artist }(-0.5=\text { English; } \\
+0.5=\text { French })\end{array}$ & $0.3^{* * * *}$ & {$[0.15,0.45]$} & 0.22 & {$[-0.08,0.51]$} & $-0.48^{*}$ & {$[-0.82,-0.14]$} \\
\hline $\operatorname{Sex}(-0.5=$ male $+0.5=$ female $)$ & $-0.21^{* *}$ & {$[-0.35,-0.07]$} & $-0.38^{* *}$ & {$[-0.59,-0.17]$} & $-0.36^{* *}$ & {$[-0.59,-0.14]$} \\
\hline Age & 0 & {$[0,0.01]$} & 0 & {$[-0.01,0.01]$} & -0.01 & {$[-0.02,0]$} \\
\hline Mother's education level & -0.07 & {$[-0.21,0.08]$} & -0.13 & {$[-0.34,0.09]$} & -0.15 & {$[-0.38,0.09]$} \\
\hline English language skills & -0.02 & {$[-0.19,0.16]$} & 0.24 & {$[-0.02,0.51]$} & $0.41^{*}$ & {$[0.11,0.7]$} \\
\hline Attachment to the artist & -0.03 & {$[-0.11,0.06]$} & 0.07 & {$[-0.05,0.2]$} & -0.04 & {$[-0.18,0.1]$} \\
\hline Concert attendance & $0.28^{* * * *}$ & {$[0.22,0.34]$} & $0.42^{* * * *}$ & {$[0.34,0.51]$} & $0.18^{* * *}$ & {$[0.08,0.28]$} \\
\hline $\begin{array}{l}\text { Accompanying }(-0.5=\text { alone; } \\
+0.5=\text { accompanied })\end{array}$ & $-0.09^{\dagger}$ & {$[-0.17,-0.01]$} & $-0.12^{\dagger}$ & {$[-0.25,0.01]$} & -0.08 & {$[-0.22,0.06]$} \\
\hline Patriotic attitudes & -0.03 & {$[-0.09,0.03]$} & -0.03 & {$[-0.12,0.06]$} & 0.02 & {$[-0.07,0.12]$} \\
\hline Language of the artist $\mathrm{x}$ attachment & $-0.21^{* * *}$ & {$[-0.32,-0.1]$} & & & & \\
\hline Language of the artist $\mathrm{x}$ accompanying & & & & & $0.68^{*}$ & {$[0.09,1.27]$} \\
\hline Venue random intercept variance & 0.01 & {$[0,0.05]$} & 0.1 & {$[0,0.33]$} & 0.02 & {$[0,0.1]$} \\
\hline Artist random intercept variance & 0.02 & {$[0,0.08]$} & 0.39 & {$[0.2,0.64]$} & 0.25 & {$[0.08,0.48]$} \\
\hline Level 1 residuals & 0.44 & {$[0.37,0.51]$} & 0.81 & {$[0.68,0.96]$} & 1.06 & {$[0.89,1.27]$} \\
\hline
\end{tabular}

Note(s): Left reverse bracket indicates that the zero is excluded from the $95 \% \mathrm{CI} ;{ }^{\dagger} p<0.05,{ }^{*} p<0.025$, ** $p \leq 0.005$ and ${ }^{* * *} p \leq 0.0005$ The
consumption of
live music

\section{te}


Finally, we observed effects of three of our covariates. First, dancing was lower for men than for women, $B=-0.36,95 \% \mathrm{CI}[-0.59,-0.14], p=0.002$. Second, dancing was higher for participants attending the concert accompanied than alone, $B=0.40,95 \% \mathrm{CI}[0.11,0.70]$, $p=0.007$. Third, dancing was positively associated with attachment to the artist, $B=0.18$, $95 \%$ CI [0.08, 0.28], $p<0.001$.

Figure 1.

Effect of the language of the artist (English vs French) on appraisal of the lyrics (left panel), unison singing (middle panel) and dancing (right panel)
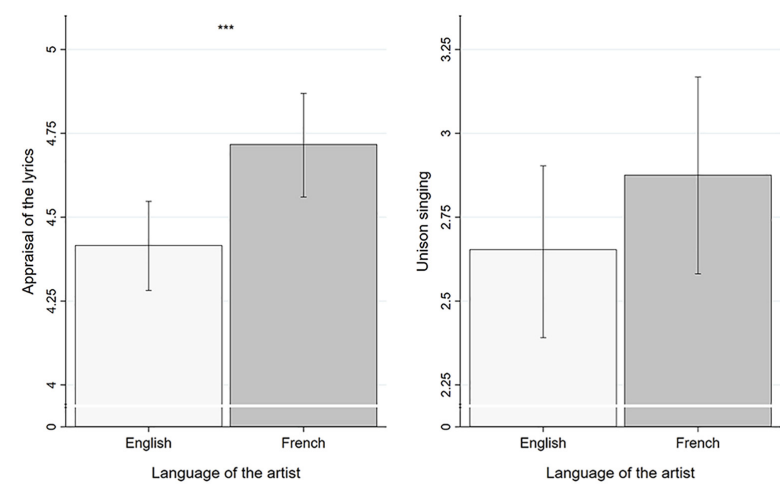

Note(s): Error bar are $95 \% \mathrm{CI} ;{ }^{* *} p \leq 0.005,{ }^{* *} p \leq 0.0005$

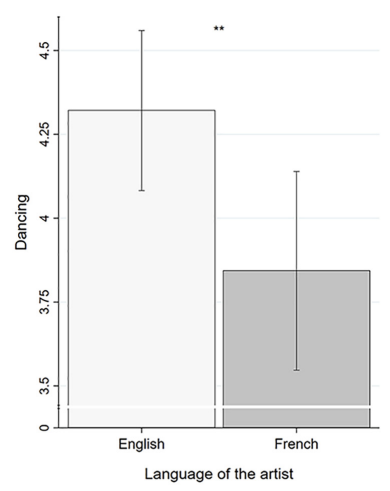

Language of the artist

\section{Figure 2.}

Effect of the language of the concert (English vs French) on appraisal of the lyric as a function of attachment to the artist (low $[-1$ $\mathrm{SD}]$ vs high [+1 SD])

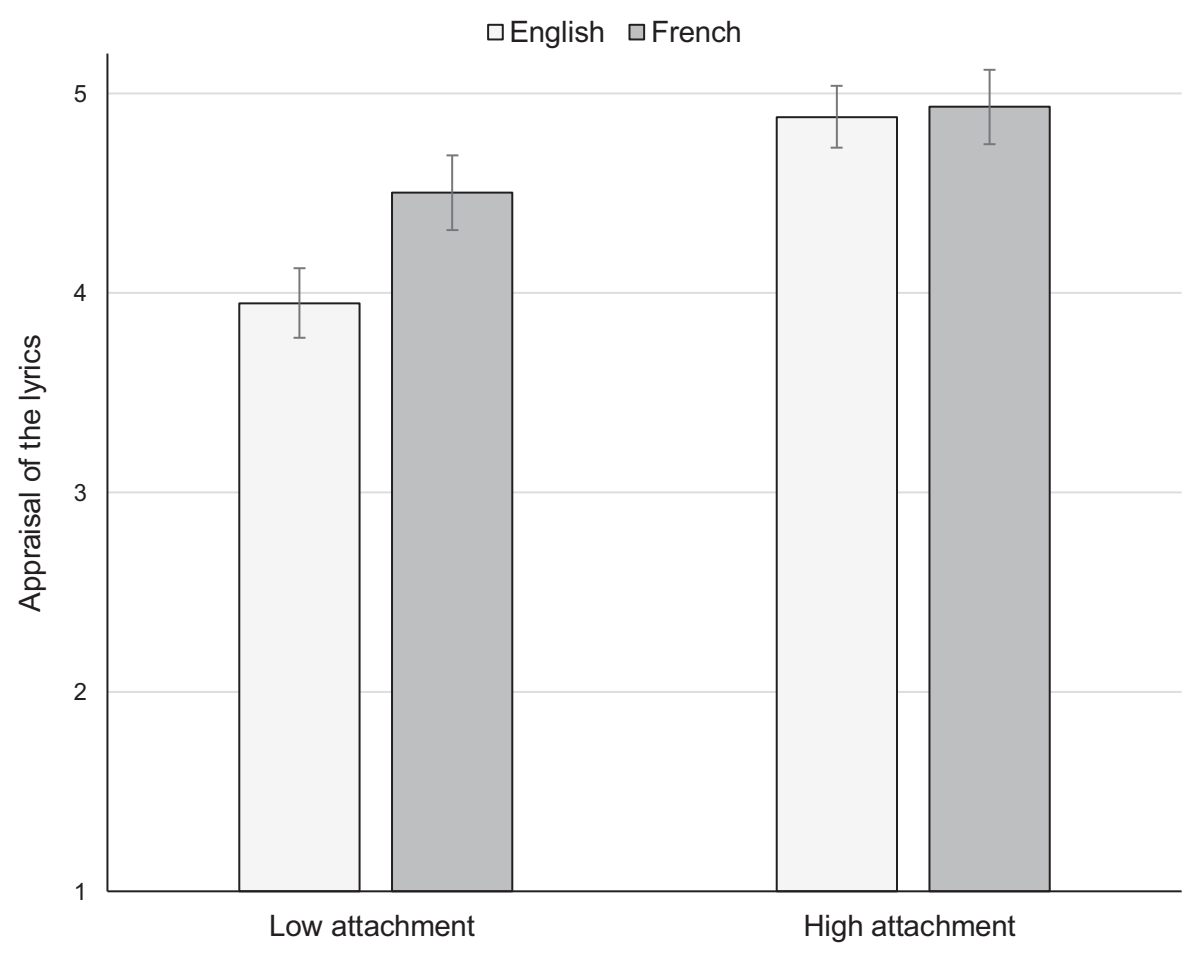

Note(s): Error bars are 95\% CI 


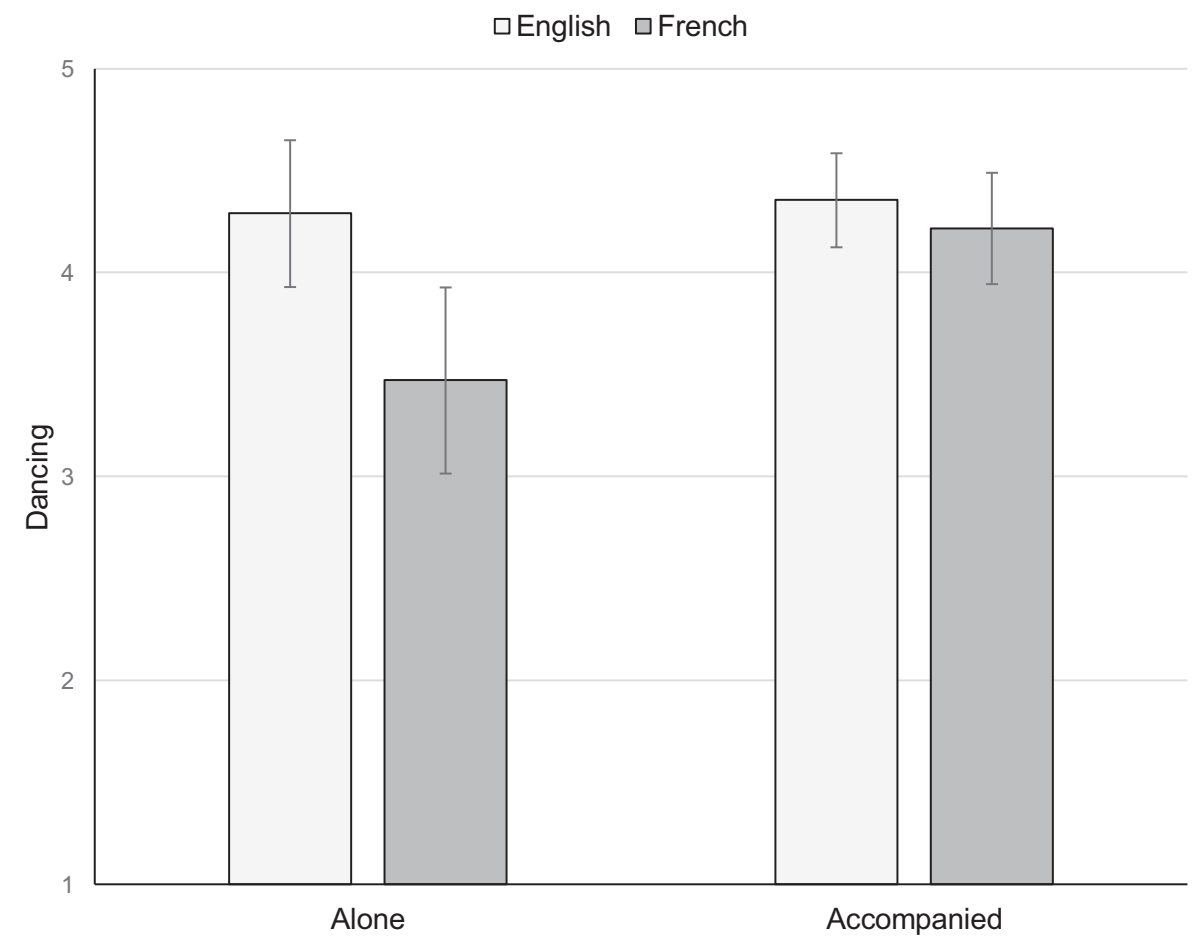

Note(s): Error bars are $95 \%$ CI

\section{The \\ consumption of live music}

Figure 3.

Effect of the language of the concert (English vs French) on dancing as a function of accompanying (alone vs accompanied)

\section{Discussion}

The present research aimed to examine the impact of language on three dimensions of live music consumption in Paris: the appraisal of the lyrics, singing in unison and dancing.

\section{French predicts a better appraisal of the lyrics than English}

We expected to observe an effect of the language of the concert on the appraisal of the lyrics, as a result of a relatively better understanding and familiarity of the national language (H1). Congruent with that prediction, we found that participants who attended concerts in French liked the lyrics better than participants who attended concerts in English. This effect interacted with the level of familiarity with the performing artist: we observed that the likeliness to appraise the lyrics in English was lower when the participant was little familiar with the artist, which was less the case for concerts in French. In other words, appraising the lyrics in English requires more preparation and anticipation; it is not as spontaneous or "natural" as when the concert is in French. This result reinforces the difference between French as a "native" language and English as a foreign language (in spite of the hegemonic and global status of English).

However, it is worth noting that - in preliminary analysis - the effect of English proficiency did not moderate the effect of language on appraisal of the lyrics. In other words, participants seeing artists performing in French reported liking the lyrics better than participants seeing artists performing in English, regardless of their language proficiency. Similar findings can be found in studies on French consumption of cultural goods, in which 
the consumption of goods in English is not correlated to a better level of English understanding (Cicchelli and Octobre, 2015). This phenomenon can be explained by the idea of "aesthetics of reception" where the literal content (i.e. lyrics) is not the centre of attention within the reception experience. Indeed, here, we cannot refer to a content-based explanation (i.e. lyrics in French are of greater quality than those in English) due to the absence of objective indicator, but the idea of "aesthetics of reception" suggests that non-native English speaking listeners pay less attention to the content of the lyrics when the concert is in English rather than in their native language. In our case, the French audience pays specific attention to the lyrics when the language of the concert is French rather than English, which is in line with a recurrent discourse within the independent French music scene (Spanu and Seca, 2016). This disposition towards the lyrics can be understood not only as a simple ability to understand the content of the lyrics that correspond to the native language but also as a more general and social "attitude" or "habit" towards national "native" languages vs the global pop idiom. It is a specific social behaviour regarding the way we experience locality in relation to language (i.e. music in national language corresponds to a greater expectation towards lyrics than music in English, regardless of the level of understanding of the latter). Currently, we still do not know if this listening practice is a French specificity or relates to a broader sense of national belonging, but we can suggest that it relates to the typical "sacralisation" and institutionalisation of national languages that occurs in most nation states, as opposed to asemantical perceptions and practices of language that English as a foreign, hegemonic language and somehow "accessible" language fosters (Spanu, 2019b) [6]. Further studies should test if this difference towards lyrics not only exists between English and other national languages but also in other listening contexts.

\section{Language of the artists does not predict singing in unison}

We expected an effect of the language of the concert on singing in unison as a result of a greater familiarity with the national language (H2). Incongruent with that prediction, we did not observe such an effect. On the one hand, one reason can be that singing in unison does not necessarily require repeating the exact same words as the artist, which enables the audience to sing regardless of their language proficiency. On the other hand, contextual variables, such as the vocal performance in itself might incite sing-along behaviours to a greater degree than internal language structure (Pawley and Müllensiefen, 2012). Indeed, the hegemonic and transnational nature of English might be involved: French people regularly listen to music in English through media, thereby being able to mimic its sounds and collectively identify with transnational music cultures as much as French culture. In addition to a sense of community, singing along is claimed to be related to intense revelry and "leaving the everyday life behind" (Pawley and Müllensiefen, 2012), which could favour the use of a foreign language such as English. But here the role of domestic vs foreign language remains unclear both allowing to escape everyday life and build communities.

We can also argue that, as a music practice, singing in unison does not create a dichotomy between national and international language in the reception of popular music. In terms of global aesthetics, we can, thus, consider singing along not only as an active mode of music consumption but also, in this case, as an inclusive practice on a linguistic level. Further studies should test if this absence of difference also exists between other languages, especially non-hegemonic ones.

\section{English predicts more dancing than French}

Finally, we expected an effect of the language of the concert on dancing as a result of a lower degree of understanding during concerts in English and a greater focus on the body (H3). Congruent with that prediction, we did observe a negative effect of language, meaning that 
participants who attended concerts in French danced less than those who attended concerts in English. Two non-mutually exclusive reasons might help understand this effect. First, we could formulate a strictly linguistic interpretation: the English language is "stress-timed," whereas the French language is "syllable-timed" (Otake et al., 1993). This difference in "language rhythm" might be associated to more danceable music features, therefore enhancing dancing practices during concerts in English. However, dancing is a social and cultural practice that cannot be entirely determined by internal language elements.

Indeed, the effect may be accounted for by the fact that France has a long tradition of "chanson française," a type of popular music whose authenticity relies on the clarity and refinement of the lyrics, whereas international pop music emphasises more the rhythm, the groove and the melody (Marc, 2014; Guibert, 2006; Looseley, 2003). This tradition resulted in the sedimentation of a French standard of production/composition in which lyrics are the focal point of music in French (Prévost-Thomas, 2018), while the body-based listening experience is more related with international pop in English (although it exists in French pop as a "minor" experience). In other words, the "foreign" language is relocated and appropriated through a specific type of embodiment in a musical context.

Besides, as a social practice, dancing is associated with the collective experience of music, especially with people we personally know. We observed that participants danced less only when the concert was in French and they were alone at these shows. One explanation could be that - similarly to unison singing's contextual variables - there is a "group" effect (due to the presence of friends) that enhances dancing, especially for shows in French that tend to be less danceable.

\section{Conclusion}

The results of our survey on live music consumption can be summarised as follows: English is positively associated with dancing, whereas French is positively associated with the appraisal of the lyrics while there was no evidence that the language of the concert was associated with differences in singing in unison. These results suggest the existence of a continuum between English and French in the context of live music consumption, where the English end is shrouded in mist in regards to lyrics, which makes its reception more mysterious and at least as exciting as the French end, but in a more embodied and collective way. All three variables were associated with previous listening to the artist, which emphasises the overall affective dimension of live music consumption and its inclusion in personal histories of cultural practices. The results are also in line with the common thought that French audiences pay a specific attention to the lyrics and confirm the idea that music in French tends to be less danceable and favour "intellectual" music consumption to some extent. This social representation is common among French bands and somehow explains the widespread practice of English singing in France, even though many counterexamples exist. Indeed, several singers do manage to make people dance when singing in French (see Stromae and Yelle for recent examples). However, the increasing use of English within French mainstream pop seems to reinforce the dichotomy between the two languages (danceable vs text based), as shown by what could be called a "code-switching composition pattern": verses are softly sung in French while choruses are intensely sung in English [7]. Further studies should test if the difference towards lyrics production and consumption in foreign and hegemonic language vs native language also exists in similar national contexts and other local contexts where languages are practiced and distributed differently (Spanu, 2020; Seca, 2020; Poliakov et al., 2020).

Besides, if we want to understand better the local meaning of languages in globalising musical contexts, we need to reconsider its relation with the symbolisation of the body in pop music (Seca, 2001), which should include a broader reflexion on gender (Thornton, 2006), as 
our results show that dancing was lower for men than for women. For instance, further studies on language reception and popular music consumption should test whether music from different countries performed in national language involves less dancing than international music in English and how it relates to gender.

The implications of these results for practitioners, policy makers and music professionals consist in a new way of considering language diversity, beyond a simple opposition between languages (domestic/native vs foreign), in the form of a continuum where languages are being practiced and experienced differently in specific localised contexts (Spanu, 2019a; Squires, 2019; Pennycook, 2010). More generally, this idea of a continuum relies on the fact that languages in musical contexts are deeply versatile, their meaning evolves constantly, depending on the many situations in which we listen to music (e.g. at home, in festivals, alone or with friends at a party, etc.) and always relate to other dimensions of social life (the body, national belonging, the gendered ritualisation of emotions, etc).

\section{Notes}

1. Even in the case of collective listening in a classroom, responses to the content of lyrics is ambivalent regarding comprehension, as shown by empirical studies on protest songs (Robinson and Hirsch, 1972).

2. The fact that the survey took place in Paris inherently limits the possibility to generalise the discussion to the rest of the country. Indeed, the Parisian population surveyed here is characterised by its relatively high education level, high English proficiency and cosmopolitan environment.

3. Mother's level of education is a more reliable indicator of social class than father's level of education (Schultz, 2002).

4. Three participants saw an artist or band mostly performing in English (i.e. Lenny Kravitz, Cats on Trees and Nicolas Cavallaro) and incorrectly indicated that the language of the concert was French. These three mistakes were corrected and their responses were changed to "English."

5. Other variables were tested in the first version of the questionnaire, such as clarity of the singing parts and level of understanding the lyrics, but they were not included in the present analysis.

6. But other foreign or regional languages (Spanu, 2015) and even invented languages (MansionVaquié, 2020) or "yaourt" (Cutler, 2000) could be considered to explore these asemantical dimensions of music (although as a minor phenomenon).

7. Some examples: "J'ai cherché" (2016) and "On dirait" (2016) from Amir, "Paris-Seychelles" (2013) from Julien Doré, "Mon Everest” (2016) from Soprano feat. Marina Kaye, "Le Temps qu'il faut” (2016) and "Are We Awake” (2016) from Tal, "Open Season (Une autre saison)” (2015) from Josef Salvat.

\section{References}

Achterberg, P., Heilbron, J., Houtman, D. and Aupers, S. (2011), “A cultural globalization of popular music? American, Dutch, French, and German popular music charts (1965 to 2006)", American Behavioral Scientist, Vol. 55, pp. 589-608, doi: 10.1177/0002764211398081.

Aleshinskaya, E. and Gritsenko, E. (2017), "Language practices and language ideologies in the popular music TV show the Voice Russia”, Language and Communication, Vol. 52, pp. 45-59, doi: 10. 1016/j.langcom.2016.08.005.

Ali, S.O. and Peynircioğlu, Z.F. (2006), "Songs and emotions: are lyrics and melodies equal partners?", Psychology of Music, Vol. 34, pp. 511-534, doi: 10.1177/0305735606067168.

Alim, S.H. and Pennycook, A. (2007), "Glocal linguistic flows: hip-hop culture(s), identities, and the politics of language education”, Journal of Language, Identity and Education, Vol. 6, pp. 89-100, doi: 10.1080/15348450701341238.

Balibar, R. (1985), L’institution du Français, Presses Universitaires de France, Paris. 
Ballico, C. and Carter, D. (2018), "A state of constant prodding: live music, precarity and regulation", Cultural Trends, Vol. 27 No. 3, pp. 203-217.

Ballou, M.J. (2009), "Singing in unison? Selling chant to the reluctant choir", Sacred Music, Vol. 136, pp. 54-56.

The
consumption of
live music

Bekhuis, H., Meuleman, R. and Lubbers, M. (2013), "Globalization and support for national cultural protectionism from a cross-national perspective", European Sociological Review, Vol. 29, pp. 1040-1052, doi: 10.1093/esr/jcs080.

Bennett, A. (1997), “'Going down the Pub!: The Pub Rock Scene as a resource for the consumption of popular music", Popular Music, Vol. 16 No. 1, pp. 97-108.

Benson, P. (2013), "English and identity in East Asian popular music", Popular Music, Vol. 32 No. 1, pp. 23-33, doi: 10.1017/S0261143012000529.

Billig, M. (1995), Banal Nationalism, Sage, London.

Blommaert, J. (2010), The Sociolinguistics of Globalization, Cambridge University Press, Cambridge.

Buch, E. (2014), “À propos d’un certain jargon de l'authenticité musicale”, Noesis, Vols 22-23, pp. 57-72.

Burland, K. and Pitts, S. (Eds) (2016), Coughing and Clapping: Investigating Audience Experience, Routledge, London.

Cerquiglini, B. (2006), "Du monolinguisme français, et de la diversité", The French Review, Vol. 79 No. 5, pp. 976-983, January 13, 2020, available at: www.jstor.org/stable/25480431.

Cicchelli, V. and Octobre, S. (2015), "Sur le cosmopolitisme esthétique chez les jeunes", Le Débat, Vol. 183, pp. 101-109, doi: 10.3917/deba.183.0101.

Cicchelli, V., Octobre, S., Riegel, V., Katz-Gerro, T. and Handy, F. (2018), "A tale of three cities: aesthetico-cultural cosmopolitanism as a new capital among youth in Paris, São Paulo, and Seoul", Journal of Consumer Culture, doi: 10.1177/1469540518818629.

Cluley, R. (2009), "Engineering great moments: the production of live music", Consumption Markets and Culture, Vol. 12 No. 4, pp. 373-388, doi: 10.1080/10253860903204576.

Conseil supérieur de l'audiovisuel (CSA) (1996), "Entrée en vigueur du quota de $40 \%$ de chansons francophones à la radio", available at: http://www.csa.fr/Radio/Le-suivi-des-programmes/Ladiffusion-de-chansons-d-expression-francaise/Entree-en-vigueur-du-quota-de-40-de-chansonsfrancophones-a-la-radio.

Cotton, J.L. (1981), “A review of research on Schachter's theory of emotion and the misattribution of Arousal”, European Journal of Social Psychology, Vol. 11 No. 4, pp. 365-397.

Cramer, A.O., van Ravenzwaaij, D., Matzke, D., Steingroever, H., Wetzels, R., Grasman, R.P.P.P., Waldorp, L.J. and Wagenmakers, E.-J. (2016), "Hidden multiplicity in exploratory multiway ANOVA: prevalence and remedies", Psychonomic Bulletin and Review, Vol. 23, pp. 640-647, doi: 10.3758/s13423-015-0913-5.

Crossley, N. (2015), "Music worlds and body techniques: on the embodiment of musicking", Cultural Sociology, Vol. 9 No. 4, pp. 471-492, doi: 10.1177/1749975515576585.

Crystal, D. (2012), English as a Global Language, Cambridge University Press, Cambridge, NY.

Cutler, C. (2000), "Chanter en yaourt': pop music and language choice in France”, Popular Music and Society, Vol. 24 No. 3, pp. 117-133, doi: 10.1080/03007760008591779.

Dauncey, H. (2017), Popular Music in France from Chanson to Techno: Culture, Identity and Society, Routledge, London.

De Figueiredo, E.H.D. (2015), "English identity and Manguebeat in Brazil: English identity and Manguebeat in Brazil”, World Englishes, Vol. 34, pp. 456-470, doi: 10.1111/weng.12152.

De Meyer, G. (1996), "Cultural globalization and local identity: the case of Belgian popular music", Popular Music and Society, Vol. 20 No. 1, pp. 123-134.

Decrop, A. and Derbaix, M. (2014), "Artist-related determinants of music concert prices”, Psychology and Marketing, Vol. 31 No. 8, pp. 660-669. 
Devonish, H. and Jones, B. (2017), "Jamaica: a state of language", Music and Crisis of Nation, Vol. 13 No. 2, pp. 129-145, doi: 10.4000/volume.5321.

Dewaele, J. (2010), Emotions in Multiple Languages, Springer, Palgrave Macmillan, London.

Dewaele, J.M. (2015), "From obscure echo to language of the heart: multilinguals' language choices for (emotional) inner speech", Journal of Pragmatics, Vol. 87, pp. 1-17.

Dorin, S. (2005), "La globalisation du rock vue de Calcutta”, Volume!, Vol. 4, pp. 139-150, doi: 10.4000/ volume.1714.

Duncan, D. (2017), "Australian singer, American features: performing authenticity in country music", Language and Communication, Vol. 52, pp. 31-44, doi: 10.1016/j.langcom.2016.08.004.

Dunn, E.C., Richmond, T.K., Milliren, C.E. and Subramanian, S.V. (2015), "Using cross-classified multilevel models to disentangle school and neighborhood effects: an example focusing on smoking behaviors among adolescents in the United States", Health and Place, Vol. 31, pp. 224-232, doi: 10.1016/j.healthplace.2014.12.001.

Education First (2019), "English proficiency index", available at: http://www.ef.com/ca/epi/.

Farquharson, J.T. (2017), "Linguistic ideologies and the historical development of language use patterns in Jamaican music", Language and Communication, Vol. 52, pp. 7-18.

Forsdick, C. (2017), "Global France, global French: beyond the monolingual”, Contemporary French Civilization, Vol. 42 No. 1, pp. 13-29.

Franque, A. (2015), “Chanson Française: les radios filent un mauvais quota”, Liberation, September 16, available at: www.liberation.fr.

Frith, S. (1989), "Why do songs have words?", Contemporary Music Review, Vol. 5, pp. 77-96, doi: 10. 1080/07494468900640551.

Guibert, G. (2003), “'Chantez-vous en French ou en anglais?': le choix de la langue dans le rock en France", Volume!, Vol. 2, pp. 83-98, doi: 10.4000/volume.2266.

Guibert, G. (2006), La Production de la Culture: le cas des Musiques Amplifiées en France, Mélanie Séteun/IRMA, Nantes/Paris.

Guibert, G. and Sagot-Duvauroux, D. (2013), Musiques Actuelles: ça Part en Live. Mutations Economiques d'une Filière Culturelle, IRMA/Deps, Paris.

Hewer, P. and Hamilton, K. (2010), "On emotions and salsa: some thoughts on dancing to rethink consumers", Journal of Consumer Behaviour, Vol. 9, pp. 113-125.

Holt, F. (2010), "The economy of live music in the digital age", European Journal of Cultural Studies, Vol. 13 No. 2, pp. 243-261.

Jackson, J.A. (2004), Singing in My Soul: Black Gospel Music in a Secular Age, University of North Carolina Press.

Jin, D.Y. and Ryoo, W. (2014), "Critical interpretation of hybrid K-pop: the global-local paradigm of English mixing in lyrics", Popular Music and Society, Vol. 37, pp. 113-131, doi: 10.1080/ 03007766.2012.731721.

Jones, R. and Merriman, P. (2009), "Hot, banal and everyday nationalism: bilingual road signs in Wales", Political Geography, Vol. 28 No. 3, pp. 164-173.

Kahnke, C. (2013), "Transnationale teutonen: rammstein representing the berlin republic", Journal of Popular Music Studies, Vol. 25, pp. 185-197, doi: 10.1111/jpms.12023.

Krause, T. (2008), “Amerrrika ist wunderrrbarrr': promotion of Germany through radio Goethe's cultural export of German popular music to North America", Popular Music, Vol. 27, pp. 225-242, doi: 10.1017/S0261143008004042.

Larkey, E. (1992), “Austropop: popular music and national identity in Austria”, Popular Music, Vol. 11, pp. 151-185, doi: 10.1017/S0261143000004980.

Larkey, E. (2000), "Just for fun? Language choice in German popular music", Popular Music and Society, Vol. 24 No. 3, pp. 1-20. 
Looseley, D. (2003), Popular Music in Contemporary France: Authenticity, Politics, Debate, Berg, Oxford.

Mansion-Vaquié, J. (2020), "La voix de Klokochazia, Typologie vocale, langue et personnages: le musical au service d'une cosmogonie", Vols 16:2-17:1 No. 1, pp. 109-123, available at: https:// www.cairn.info/revue-volume-2020-1-page-109.htm.

Marc, I. (2014), “Aznavour ou le drame nostalgique populaire”, Volume!, Vol. 11 No. 1, pp. 55-67.

Marc Martínez, I. (2011), "De la poésie avant toute chose: pour une approche textuelle des musiques amplifiées”, Synergies, Vol. 4, pp. 51-61.

Mattelart, A. (2015), "Du bon sauvage au sous-développé", Une Anthologie en Trois Volumes (19701986), Mines ParisTech, Paris.

Meuleman, R. and Lubbers, M. (2014), "The social distinction in having domestic vs foreign favorite music artists”, Poetics, Vol. 45, pp. 55-71, doi: 10.1016/j.poetic.2014.06.003.

Meuleman, R., Bekhuis, H., Lubbers, M. and Scheepers, P. (2013), "Own culture first? Nationalism and the preference for national cultural goods", International Journal of Public Opinion Research, Vol. 25, pp. 436-458, doi: 10.1093/ijpor/eds024.

Mihalcea, R. and Strapparava, C. (2012), "Lyrics, music, and emotions", Proceedings of the 2012 Joint Conference on Empirical Methods in Natural Language Processing and Computational Natural Language Learning, Association for Computational Linguistics, Stroudsburg, PA, pp. 590-599.

Mitchell, T. (Ed.) (2001), Global Noise: Rap and Hip-Hop outside the USA, Wesleyan University Press, Middletown, CT.

Morio, J. (2015), Chanson Francophone : les Radios Montent le ton Contre le Durcissement des Quotas, Le Monde, September 25, available at: www.lemonde.fr.

Morton, C. (2013), "Singing in unison, singing in harmony: civic mentorship and choral communities", The Phenomenon of Singing, Vol. 3, pp. 155-163.

Moscovici, S. (1985), The Age of the Crowd: A Historical Treatise on Mass Psychology, 1st ed., Cambridge University Press, Cambridge, In French Language: 1981.

Moser, S. (2007), "Media modes of poetic reception", Poetics, Vol. 35, pp. 277-300, doi: 10.1016/j.poetic. 2007.01.002.

Ninoshvili, L. (2009), "The poetics of pop polyphony: translating Georgian Song for the World", Popular Music and Society, Vol. 32 No. 3, pp. 407-424.

Nowak, R. and Bennett, A. (2014), "Analysing everyday sound environments: the space, time and corporality of musical listening”, Cultural Sociology, Vol. 8 No. 4, pp. 426-442, doi: $10.1177 /$ 1749975514532262.

Octobre, S. (2014), Deux pouces et des neurones: les cultures juvéniles de l'ère médiatique à l'ère numérique, Ministère de la Culture et de la Communication, Secrétariat Général, Département des études, de la Prospective et des Statistiques: la Documentation Française, Paris.

Otake, T., Hatano, G., Cutler, A. and Mehler, J. (1993), "Mora or syllable? Speech segmentation in Japanese”, Journal of Memory and Language, Vol. 32, pp. 258-278, doi: 10.1006/jmla.1993.1014.

Packer, J. and Ballantyne, J. (2011), "The impact of music festival attendance on young people's psychological and social well-being", Psychology of Music, Vol. 39 No. 2, pp. 164-181.

Pawley, A. and Müllensiefen, D. (2012), "The science of singing along: a quantitative field study on sing-along behavior in the north of England", Music Perception, Vol. 30 No. 2, pp. 129-146.

Pennycook, A. (2006), Global Englishes and Transcultural Flows, Routledge, London.

Pennycook, A. (2010), Language as a Local Practice, Routledge, New York, NY.

Poirrier, P. (2006), L'État et la Culture en France au XXe Siècle, Le Livre de Poche, Paris.

Poliakov, S., Omelchenko, E. and Garifzyanova, A. (2020), "Holding onto your roots: Tatar-language rap in post-Soviet Kazan”, Popular Music and Society, Vol. 43 No. 4, pp. 401-413, doi: 10.1080/ 03007766.2020.1730650. 
Prévost-Thomas, C. (2018), "Chanson Française: between musical realities and social representations", in Guibet, G. and Rudent, C. (Eds), Made in France: Studies in Popular Music, Routledge, London.

Regev, M. (2011), "Pop-rock music as expressive isomorphism: blurring the national, the exotic, and the cosmopolitan in popular music", American Behavioral Scientist, Vol. 55 No. 5, pp. 558-573.

Regourd, S. (2004), L'exception Culturelle, Presses universitaires de France, Paris.

Reynaud, F. (2016), Comprendre les Quotas de Chansons Francophones à la Radio, available at: www. lemonde.fr.

Rimé, B. (2005), Le Partage Social des Émotions, PUF, Paris.

Robinson, J. and Hirsch, P. (1972), “Teenage response to rock and roll protest songs", in Denisoff, R.S. and Peterson, R.A. (Eds), The Sounds of Social Change: Studies in Popular Culture, Rand McNally, Chicago.

Schachter, S. (1964), "The interaction of cognitive and physiological determinants of emotional state", in Berkowitz, L. (Ed.), Advances in Experimental Social Psychology, Academic Press, New York, NY, pp. 49-80.

Schachter, S. and Singer, J. (1962), "Cognitive, social, and physiological determinants of emotional state", Psychological Review, Vol. 69 No. 5, pp. 379-399.

Schiller, H.I. (1984), Communication and Cultural Domination, M.E. Sharpe, Armonk.

Schubert, E. (2013), "Emotion in popular music: a psychological perspective”, Volume!, Vol. 10, pp. 265-266, doi: 10.4000/volume.3626.

Schultz, P.T. (2002), "Why governments should invest more to educated girls", World Development, Vol. 30, pp. 207-225.

Seca, J.-M. (2001), Les Musiciens Underground, Presses universitaires de France, Paris.

Seca, J.M. (2009), "Le fil de la devise: les trois dimensions de l'authenticité dans les musiques populaires underground”, Sociétés, Vol. 104 No. 2, pp. 13-26.

Seca, J. (2020), "La diffusion du rap: conventionnalisme et originalité dialectale en Italie, en général, et à Naples, en particulier", Sens-Dessous, Vol. 25 No. 1, pp. 111-122, doi: 10.3917/sdes.025.0111.

Sinclair, G. and Green, T. (2016), "Download or stream? Steal or buy? Developing a typology of today's music consumer", Journal of Consumer Behaviour, Vol. 15, pp. 3-14, doi: 10.1002/cb.1526.

Sommet, N. and Morselli, D. (2017), "Keep calm and learn multilevel logistic modeling: a simplified three-step procedure using Stata, R, mplus, and SPSS”, International Review of Social Psychology, Vol. 30 No. 1, pp. 203-218, doi: 10.5334/irsp.90.

Spanu, M. (2015), "Alternative globalization in southern France: minority language as a creative tool in Occitan popular music", in Helms, D. and Phleps, T. (Eds), Speaking in Tongues, Transcript Verlag, Bielefeld, pp. 81-97.

Spanu, M. (2019a), "Pour une approche critique de la diversité des langues chantées dans les musiques populaires àl'ère de la mondialisation numérique", Questions de Communication, Vol. 35 No. 1, pp. 281-303, available at: https://www.cairn.info/revue-questions-de-communication-2019-1page-281.htm.

Spanu, M. (2019b), "Sacred languages of pop: rooted practices in globalized and digital French popular music", Open Cultural Studies, Vol. 3 No. 1, pp. 195-206, doi: 10.1515/culture-2019-0018.

Spanu, M. (2020), "Chanter en langue régionale dans un contexte global: Les Musiques Occitanes entre pop, folk et avant-garde", Hermès, La Revue, Vol. 86 No. 1, pp. 130-133.

Spanu, M. and Seca, J.-M. (2016), "Pratiques linguistiques et usages de l'anglais dans les musiques électro-amplifiées en France: le cas des spectacles à L'International”, French Politics, Culture and Society, Vol. 34, pp. 122-142.

Squires, L. (2019), "Genre and linguistic expectation shift: evidence from pop song lyrics”, Language in Society, Vol. 48 No. 1, pp. 1-30. 
Stratton, V.N. and Zalanowski, A.H. (1994), "Affective impact of music vs Lyrics", Empirical Studies of the Arts, Vol. 12 No. 2, pp. 173-184, doi: 10.2190/35T0-U4DT-N09Q-LQHW.

Sullivan, C. (2019), Pop 2.0: How Globalised Music Created a New Kind of Star, The Guardian, available at: https://www.theguardian.com/music/2019/feb/06/pop-2-0-how-globalised-music-created-a-new-kindconsumption of of-star?utm_source=newsletter_270\&utm_medium =email\&utm_campaign=music-world-news.

Szego, K. (2003), "Singing Hawaiian and the aesthetics of incomprehensibility", in Berger, H.M. and Carroll, M.T. (Eds), Global Pop, Local Language, University Press of Mississippi, Jackson.

Taylor, T.D. (2014), Global Pop: World Music, World Markets, Routledge, London.

Thornton, S. (2006), “Understanding hipness: 'subcultural capital' as feminist tool”, in Bennett, A., Shank, B. and Toynbee, J. (Eds), The Popular Music Studies Reader, Routledge, London, pp. 99-105.

Van der Hoeven, A., Janssen, S. and Driessen, S. (2016), "Articulations of identity and distinction: the meanings of language in Dutch popular music", Popular Music and Society, Vol. 39 No. 1, pp. 43-58.

Véronique, J. and Martiréné, I. (2015), Indicateurs de la Diversité Musicale dans le Paysage Radiophonique, Observatoire de la musique, Cité de la musique, Paris.

Wall, I.M. (1987), "Les accords blum-byrnes. La modernisation de la France et la guerre froide", Vingtième Siècle, Vol. 13 No. 1, pp. 45-62, doi: 10.3406/xxs.1987.1825.

Wallach, J. (2003), "Goodbye my blind Majesty: music, language, and politics in the Indonesian underground", in Berger, H.M. and Carroll, M.T. (Eds), Global Pop, Local Language, University Press of Mississippi, Jackson.

Wolther, I. (2008), "Die perfekte welle': possible solutions to the crisis of the international music industry with the help of national language music", Popular Music, Vol. 27 No. 2, pp. 289-297.

Yzerbyt, V.Y., Muller, D. and Judd, C.M. (2004), “Adjusting researchers' approach to adjustment: on the use of covariates when testing interactions", Journal of Experimental Social Psychology, Vol. 40, pp. 424-431, doi: 10.1016/j.jesp.2003.10.001. 


\section{Appendix}

\begin{tabular}{|c|c|c|c|}
\hline Id & Artist/band & Language & Location \\
\hline 1. & Adron & French & New Morning \\
\hline 2. & Albin de la Simone & French & Philharmonie de Paris \\
\hline 3. & Alvvays & English & Badaboum \\
\hline 4. & Angèle & French & Olympia \\
\hline 5. & A perfect circle & English & Olympia \\
\hline 6. & Arkadin Oscar & French & FNAC Live \\
\hline 7. & Arthur $\mathrm{H}$ & French & Salle Pleyel \\
\hline 8. & Astonvilla & French & Maroquinerie \\
\hline 9. & Benabar & French & Grand Rex \\
\hline 10. & Benjamin Biolay & French & Folies Bergères \\
\hline 11. & Billy Idol & English & Zenith \\
\hline 12. & Blind Digital Citizen & French & Badaboum \\
\hline 13. & Booba & French & U Arena \\
\hline 14. & Borns & English & Trabendo \\
\hline 15. & Brigitte & French & Olympia \\
\hline 16. & Britney Spears & English & Accorhotel Arena \\
\hline 17. & BRNS & English & Petit bain \\
\hline 18. & Caesaria & English & Trois Baudets \\
\hline 19. & Calogero & French & Accorhotel Arena \\
\hline 20. & Cats on trees & English & Cigale \\
\hline 21. & Charlie Winston & English & Trianon \\
\hline 22. & Christine and the queens & French & FNAC Live \\
\hline 23. & Claire Laffut & French & Trois baudets \\
\hline 24. & Colombine & French & Olympia \\
\hline 25. & Coming Soon & English & Point Éphémère \\
\hline 26. & Concrete Knives & English & Maroquinerie \\
\hline 27. & Corine & French & FGO Barbara \\
\hline 28. & Corson Ollebirde & English & La Cigale \\
\hline 29. & Courtney Barnett & English & Bataclan \\
\hline 30. & Courtney Marie Andrews & English & Petit Bain \\
\hline 31. & Cyril Mokaiesh & French & FNAC Live \\
\hline 32. & Dead sea & English & Badaboum \\
\hline 33. & Debout sur le Zinc & French & Petit Bain \\
\hline 34. & Demi portion & French & Olympia \\
\hline 35. & Di-meh & French & Boule Noire \\
\hline 36. & Dinos & French & Boule Noire \\
\hline 37. & Disiz & French & Citadium \\
\hline 38. & Django django & English & FNAC Live \\
\hline 39. & Drenge & English & Grand rex \\
\hline 40. & $\mathrm{EDH}$ & English & Espace B \\
\hline 41. & ED Sheeran & English & Trianon \\
\hline 42. & Elliot Maginot & English & Pop up du label \\
\hline 43. & En Attendant Ana & English & Maroquinerie \\
\hline 44. & Feu! Chatterton & French & Trianon \\
\hline 45. & First Aid Kit & English & Cabaret Sauvage \\
\hline 46. & François and The Atlas Mountains & English & Philharmonie de Paris \\
\hline 47. & Fred Chapellier & English & Longlaville \\
\hline 48. & Gaspard Royant & English & Folies Bergères \\
\hline 49. & Gauvain Sers & French & La Cigale \\
\hline 50. & Govrache & French & Café de la danse \\
\hline 51. & Grand Blanc & French & Solidays \\
\hline 52. & Her & English & Olympia \\
\hline 53. & Hindi Zahra & English & Philharmonie de Paris \\
\hline 54. & Hinds & English & Point Éphémère \\
\hline 55. & Holly Miranda & English & Point Éphémère \\
\hline 56. & Hyphen hyphen & English & Solidays \\
\hline 57. & IAM & French & Solidays \\
\hline 58. & Ibeyi & English & Philharmonie de Paris \\
\hline
\end{tabular}

Table A1.

IAM 


\begin{tabular}{|c|c|c|c|c|}
\hline Id & Artist/band & Language & Location & \\
\hline 59. & Iceage & English & Petit Bain & live music \\
\hline 60. & Ilaria Graziano & English & Maroquinerie & \\
\hline 61. & Imany & English & New Morning & \\
\hline 62. & In the canopy & English & Divan du monde & \\
\hline 63. & Iron Maiden & English & Zenith & \\
\hline 64. & Isaac delusion & English & Casino de Paris & \\
\hline 65. & Izia & English & Solidays & \\
\hline 66. & Jack White & English & Olympia & \\
\hline 67. & Jeanne added & English & FNAC Live & \\
\hline 68. & Jesus and Mary Chain & English & Trianon & \\
\hline 69. & John Baez & English & Olympia & \\
\hline 70. & Josh T. Pearson & English & Maroquinerie & \\
\hline 71. & Julien Doré & French & Olympia & \\
\hline 72. & Keen'V & French & Zenith & \\
\hline 73. & Killy & English & Boule Noire & \\
\hline 74. & L7 & English & Bataclan & \\
\hline 75. & La Bronze & French & Trois Baudets & \\
\hline 76. & Las Aves & English & Badaboum & \\
\hline 77. & Lauren Auder & English & Pop up du label & \\
\hline 78. & Lavilliers & French & Fête de l'Huma & \\
\hline 79. & Lenny kravitz & English & Olympia & \\
\hline 80. & Leonie & French & Carmen & \\
\hline 81. & Les amants & French & FGO Barbara & \\
\hline 82. & Les négresses vertes & French & Cabaret Sauvage & \\
\hline 83. & Les Ogres de Barback & French & Trianon & \\
\hline 84. & Leyya & English & Point Éphémère & \\
\hline 85. & Liam Gallagher & English & Rock en Seine & \\
\hline 86. & Limp bizkit & English & Bataclan & \\
\hline 87. & Lofofora & French & Maroquinerie & \\
\hline 88. & Lukas Ionesco & English & Trois Baudets & \\
\hline 89. & Mabel & English & Maroquinerie & \\
\hline 90. & Mademoiselle k & English & Solidays & \\
\hline 91. & Malo' & English & Café de la danse & \\
\hline 92. & Manolo & English & Pop up du label & \\
\hline 93. & Mariscal & French & Café de la danse & \\
\hline 94. & Masego & English & Trianon & \\
\hline 95. & Mesparrow & English & Petit Bain & \\
\hline 96. & Mices & English & Petit Bain & \\
\hline 97. & Milkandbone & English & Boule Noire & \\
\hline 98. & Minuit & French & FNAC Live & \\
\hline 99. & Mumford and sons & English & Olympia & \\
\hline 100. & Mustang & French & Folies Bergères & \\
\hline 101. & Natas Loves You & English & Point Éphémère & \\
\hline 102. & Nathalie Prass & English & Maroquinerie & \\
\hline 103. & Nekfeu & French & FNAC Live & \\
\hline 104. & Nev Cottee & English & FGO Barbara & \\
\hline 105. & Nick Cave & English & Grand Rex & \\
\hline 106. & Nickelback & English & Palais des sports & \\
\hline 107. & Nicola cavallaro & English & Café de la danse & \\
\hline 108. & Night beats & English & Point Éphémère & \\
\hline 109. & Niska & French & Zenith & \\
\hline 110. & Noah Kahan & English & Boule Noire & \\
\hline 111. & Noel Gallagher & English & Grand Rex & \\
\hline 112. & Nungan & English & Bus palladium & \\
\hline 113. & Of monsters and men & English & Trianon & \\
\hline 114. & Oldelaf & French & Trianon & \\
\hline 115. & Orouni & English & Trois Baudets & \\
\hline 116. & Ought & English & Maroquinerie & \\
\hline 117. & Peach pit & English & Cabaret Sauvage & \\
\hline 118. & Pierre Lapointe & French & FNAC Live & \\
\hline & & & (continued) & Table A1. \\
\hline
\end{tabular}




\begin{tabular}{|c|c|c|c|c|}
\hline & Id & Artist/band & Language & Location \\
\hline & 119. & Pogo car crash control & French & Maroquinerie \\
\hline & 120. & Pomme & French & La Cigale \\
\hline & 121. & Rémi Parson & French & Espace B \\
\hline & 122. & Rhys Lewis & English & Pop up du label \\
\hline & 123. & Ringo Starr and his all starr band & English & Olympia \\
\hline & 124. & Roger jr & French & Trois Baudets \\
\hline & 125. & Roger waters & English & U Arena \\
\hline & 126. & Romance & French & Trois Baudets \\
\hline & 127. & Rostam & English & Point Éphémère \\
\hline & 128. & Sam Smith & English & Zenith \\
\hline & 129. & Sarah Blasko & English & Trois Baudets \\
\hline & 130. & Scorpions & English & Accorhotel Arena \\
\hline & 131. & Sébastien Schuller & English & Maroquinerie \\
\hline & 132. & Skip the use & English & Place de la République \\
\hline & 133. & Sophie Hunger & English & La Cigale \\
\hline & 134. & State Champs & English & Maroquinerie \\
\hline & 135. & Still & English & Maroquinerie \\
\hline & 136. & Sting & English & Olympia \\
\hline & 137. & $\mathrm{StU}$ & English & Bataclan \\
\hline & 138. & Svinkels & French & Olympia \\
\hline & 139. & Temples & English & Grand Rex \\
\hline & 140. & Tess Parks and Anton Newcombe & English & Maroquinerie \\
\hline & 141. & The Bawdies & English & Boule Noire \\
\hline & 142. & The Cage & English & Rock en Seine \\
\hline & 143. & The go team & English & Maroquinerie \\
\hline & 144. & The horrors & English & Trianon \\
\hline & 145. & The Kinds & English & Maroquinerie \\
\hline & 146. & Thérapie taxi & French & La Cigale \\
\hline & 147. & The War On Drugs & English & Philharmonie de Paris \\
\hline & 148. & The Who & English & Zenith \\
\hline & 149. & Thomas Dutronc & French & Flow \\
\hline & 150. & Two Feet & English & Boule Noire \\
\hline & 151. & Vianney & French & Accorhotel Arena \\
\hline & 152. & Victor Osair & French & Trois Baudets \\
\hline & 153. & Vince Staples & English & Elysée Montmartre \\
\hline & 154. & Wild Child & English & Trois Baudets \\
\hline & 155. & Yelle & French & Hippodrome de Longchamps \\
\hline & 156. & Ysé Sauvage & English & Trois Baudets \\
\hline & 157. & Zebda & French & Solidays \\
\hline & 158. & Zoufris & French & Solidays \\
\hline Table A1. & 159. & Zëro & English & Petit Bain \\
\hline
\end{tabular}

Table A2.

Coefficient estimates (Bs) and $95 \%$ credibility intervals $(95 \%$ CIs) for the cross-classified multilevel linear regression models estimating the effects of the language of the artist and the covariates on appraisal of the lyrics, unison singing and dancing, while excluding covariates

\begin{tabular}{|c|c|c|c|c|c|c|}
\hline & \multicolumn{2}{|c|}{$\begin{array}{l}\text { Appraisal of the } \\
\text { lyrics }\end{array}$} & \multicolumn{2}{|c|}{ Unison singing } & \multicolumn{2}{|c|}{ Dancing } \\
\hline & $B$ & $95 \% \mathrm{CI}$ & $B$ & $95 \%$ CI & $B$ & $95 \% \mathrm{CI}$ \\
\hline Intercept & $4.55^{* * * *}$ & {$[4.45,4.65]$} & $2.81^{* * * *}$ & {$[2.56,3.05]$} & $4.17^{\text {***** }}$ & {$[3.99,4.35]$} \\
\hline $\begin{array}{l}\text { Language of the artist } \\
(-0.5=\text { English; }+0.5=\text { French })\end{array}$ & $0.3^{* * *}$ & {$[0.13,0.47]$} & 0.24 & {$[-0.08,0.57]$} & -0.2 & {$[-0.51,0.11]$} \\
\hline $\begin{array}{l}\text { Venue random intercept } \\
\text { variance }\end{array}$ & 0.02 & {$[0,0.08]$} & 0.25 & {$[0.06,0.57]$} & 0.04 & {$[0,0.17]$} \\
\hline $\begin{array}{l}\text { Artist random intercept } \\
\text { variance }\end{array}$ & 0.02 & {$[0,0.09]$} & 0.48 & {$[0.26,0.77]$} & 0.4 & {$[0.18,0.69]$} \\
\hline Level 1 residuals & 0.58 & {$[0.49,0.67]$} & 1.03 & {$[0.86,1.22]$} & 1.11 & {$[0.93,1.33]$} \\
\hline
\end{tabular}


About the authors

Michael Spanu holds a PhD in sociology (Social Sciences Laboratory of Lorraine [2L2S], University of Lorraine). He is a postdoctoral fellow in Social Sciences and Cultural Industries at the Centro de Investigación sobre América del Norte (Universidad Nacional Autónoma de México). His work focuses on language diversity and popular music. His area of expertise also encompasses night studies and the digital turn of the live music industry. Michael Spanu is the corresponding author and can be contacted at: spanu.michael@gmail.com

Nicolas Sommet is a PhD in social psychology at the Life Course and Inequality Research Centre (LINES-University of Lausanne). His research focuses on motivation, competition and income inequality. His area of expertise also encompasses multilevel modelling.

Jean-Marie Seca is full professor of sociology at the Social Sciences Laboratory of Lorraine (2L2S), University of Lorraine. He is specialized in the anthropology of underground music.

For instructions on how to order reprints of this article, please visit our website: 